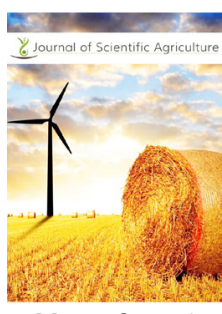

ISSN: $2184^{-0} 0261$
Received: February 13, 2021 Revised: July 06, 2021 Accepted: July 07, 2021 Published: July 17, 2021

*Corresponding Author: M. M. Hossain, E-mail: dr.mobarakphd@ gmail.com

\section{Optimum planting date for the maximum tuber yield of tropical sugar beet (Beta vulgaris L.) genotypes in the Old Brahmaputra Floodplain}

\author{
M. M. Hossain ${ }^{\text {* }}$, M. A. Kader', and M. A. Kashem² \\ 'Department of Agronomy, Bangladesh Agricultural University, Mymensingh-2202, Bangladesh, ${ }^{2}$ Department of Soil \\ Science, Sylhet Agricultural University, Sylhet-3100, Bangladesh
}

\begin{abstract}
Planting dates for a crop is a non-monetary input but plays a significant role in increasing the yield. Therefore, identifying genotype-specific planting dates is essential for obtaining the economic yield of tropical sugar beet. By this perspective, a field experiment was conducted at the Agronomy Field Laboratory, Bangladesh Agricultural University in Bangladesh, from November 2015 to April 2016. Five sugar beet genotypes: Shubhra, Cauvery, EB-0616, EB-0626, and EB-0809 planted on four dates: 10, 20,30 November, and 10 December. Treatments were laid out in a split-plot design replicated three times. Data revealed that planting on 10 November genotype EB-0809 produced the highest tuber yield, which was significantly superior to other gernotypes planted on other dates. It was found that every ten days delay of planting from 10 November to 30 December reduced the tuber yield by 30,43 , and $55 \%$, respectively. Results confirmed that planting the EB-0809 genotype on 10 November is ideal to obtain the highest tuber yield of tropical sugar beet in Bangladesh.
\end{abstract}

KEYWORDS: Planting date, genotype, tropical sugar beet, yield

\section{INTRODUCTION}

Sugar beet (Beta vulgaris L.) ranks second next to sugarcane, producing annually about $40 \%$ of total sugar production all over the world in terms of the world's sugar production (El-Hag et al., 2015). It is a temperate crop, generally grown in Europe, North America, and Asia's temperate zones. France, Germany, Russia, the USA, and Ukraine are the most sugar beet producing countries (Paul et al., 2018). But recently developed, several genotypes can successfully be grown in tropical regions. Tropical sugar beet brings significant agronomic, environmental, and advantages to many tropical countries such as India, Pakistan, Sudan, etc. (Islam et al., 2013). Compared to sugarcane, this tropical sugar beet can be grown in relatively dry areas with substantially less water. It is faster growing and can be harvested after five months allowing farmers to produce a second crop on the same land. Tropical sugar beet is a short duration crop (5-6 months longer having 14-20\% Brix) than 12-14 months longer with 10-12\% Brix content sugarcane (Khan et al., 2020). Due to the acute shortage of sugarcane as raw materials, most of the sugar mills remain inoperative for a particular period in Bangladesh. In this regard, sugar beet might be an excellent alternative to sugarcane in Bangladesh by enhancing the sugar mills' processing facilities.

Planting time has a profound bearing on the yielding ability of tropical sugar beet. Tropical sugar beet varieties require an optimum temperature range of $20-25^{\circ} \mathrm{C}$ for germination, $30-35^{\circ} \mathrm{C}$ for growth and development, and $25-35^{\circ} \mathrm{C}$ for sugar accumulation, wherein the night $15-20^{\circ} \mathrm{C}$ is suitable(Gobarah et al., 2019). This crop does not prefer high rainfall, which may affect the development of tuber and sugar synthesis. This climatic condition requirement triggers optimum seeding dates for maximum yield of tropical sugar beet. Past investigations have studied the effect of planting dates on the yield and quality of sugar beet and confirmed that the identification of genotype-specific planting date is essential for this crop's economic outcome. Refay (2010) and Singh et al. (2019) found 15 October was the ideal planting date for sugar beet cultivation. It recorded earlier root swelling, higher root yield, and higher sugar yield and quality.

Furthermore, the maximum root and sucrose yield of Cauvery, Shubhra, and EB-0616 was found by planting in early November

Copyright: $\odot$ The authors. This article is open access and licensed under the terms of the Creative Commons Attribution License (http://creativecommons.org/licenses/by/4.0/) which permits unrestricted, use, distribution and reproduction in any medium, or format for any purpose, even commercially provided the work is properly cited. Attribution - You must give appropriate credit, provide a link to the license, and indicate if changes were made. 
in Bangladesh (Hossain et al., 2015). Therefore, planting time is the most crucial factor affecting the yield of tropical sugar beet to a great extent. Generally, the time of planting of sugar beet at any location is decided by the growing area's prevailing temperature. It is crucial to find out a genotypespecific optimum planting date to obtain maximum beet yield from tropical sugar beet in Bangladesh. The research work was undertaken to find out the optimum planting time and growth pattern of sugar beet in Bangladesh under tropical climatic condition by considering the above facts.

\section{MATERIALS AND METHODS}

\section{Experimental Site}

This experiment was conducted at the Field Laboratory of the Department of Agronomy of Bangladesh Agricultural University (BAU). That located in Bangladesh located geographically at $24.75^{\circ} \mathrm{N}$ latitude and $90.50^{\circ} \mathrm{E}$ longitudes at an average altitude of $18 \mathrm{~m}$ above the mean sea level.

\section{Edaphic and Climatic Environments}

The experimental field belongs to the Old Brahmaputra Floodplain of predominantly dark grey non-calcareous alluvium soils. The testing area was flood-free medium-high land, and the soil texture was sandy clay loam $(50,23$, and $27 \%$ of sand, silt, and clay, respectively), having $\mathrm{pH} 7.2$.

The research site was characterized by tropical climatic conditions with high temperature, high humidity, and heavy monsoon rainfall with the occasional gusty wind in April-September and low precipitation with moderately low-temperature during October-March. The maximum temperature varies from $32.3-33.5^{\circ} \mathrm{C}$ during April-June, while January was the coldest month. About $95 \%$ rainfall and relative humidity were received during April-September. The rest of the rain was very unevenly distributed and most uncertain. Sunshine hours differed much during the months of rainfall due to the cloudy weather.

\section{Experimental Treatments and Design}

This study comprised five tropical sugar beet genotypes: Shubhra, Cauvery, EB-0616, EB-0626, and EB-0809. They were sown on four different dates at ten days, starting from 10 November - 10 December in 2015. Treatments were laid out in a split-plot design, assigning the planting date in the main plots and genotype in sub-plots. The size of each plot was $5 \mathrm{~m} \times 2 \mathrm{~m}$.

\section{Crop Husbandry}

The experimental field was well prepared by plowing and cross plowing four times, followed by laddering. All weeds, stubbles, and crop residues were removed and then divided into the experimental units. The land was uniformly fertilized with $\mathrm{N}$, $\mathrm{P}_{2} \mathrm{O}_{5}, \mathrm{~K}_{2} \mathrm{O}, \mathrm{S}, \mathrm{Zn}$, and B@120, 105, 150, 18, 3.5, and $1.2 \mathrm{~kg} \mathrm{ha}^{-1}$ in the form of urea, triple super phosphate, muriate of potash, gypsum, zinc sulfate, and boric acid, respectively. Fungicides treated seeds were sown in line at the rate of single seed hill-1 at $2 \mathrm{~cm}$ depth. A distance of $50 \mathrm{~cm} \times 20 \mathrm{~cm}$ was maintained. Necessary thinning and gap-filling were done at the age of 35 days from planting to obtain one plant hill-1. Plants were kept free from weeds, which were controlled manually hoeing. According to the Bangladesh Sugarcane Research Institute (BSRI), we followed the standard agricultural practices for growing sugar beet.

\section{Measurements}

Based on the planting dates, plants were harvested at $165 \mathrm{DAE}$ from the central $2.5 \mathrm{~m} \times 2 \mathrm{~m}$ area from each plot. We had recorded data on the plant density $\mathrm{m}^{-2}$, whole plant's weight, number of green leave plant ${ }^{-1}$, length of leaf, tuber's girth and length, and finally, the fresh yield $\left(\mathrm{t} \mathrm{ha}^{-1}\right)$ of the tuber.

\section{Data Analysis}

All data were subjected to analysis of variance, and Duncan's Multiple Range Test compared the means at $\mathrm{P}<0.05$, using the statistical package program STAR.

\section{RESULTS}

The results revealed that both the planting date and genotypes and their interaction exerted significant influence $(\mathrm{P}<0.05)$ on the yield of tuber and different plant characters. Results obtained from the study discussed under the following headings as bellows:

\section{Effect of Planting Date}

Planting of tropical sugar beet at different dates significantly affected tuber yield $\left(\mathrm{t} \mathrm{ha}^{-1}\right)$ and other plant characters except for the tuber girth (Figure 1). The highest tuber yield (106.8 $\mathrm{t} \mathrm{ha}^{-1}$ ) was obtained from the 10 November planting, and yield declined gradually with planting afterward. Seeding on 10 November gave the highest plant density (97) and weight (160.5 t ha-1), while the 10 December planting gave the lowest values of 73 and $67.7 \mathrm{tha}^{-1}$, respectively. The longest tuber $(25.8 \mathrm{~cm})$ was obtained from the $10^{\text {th }}$ November planting, while the shortest $(21.4 \mathrm{~cm})$ was recorded from the $10^{\text {th }}$ December planting. The numerically (not statistically) widest tuber $(34.02 \mathrm{~cm})$ and the least $(23.36 \mathrm{~cm})$ were obtained from the 10 November and 10 December planting, respectively. The highest number of leaves plant ${ }^{-1}(32)$ was obtained from the $10^{\text {th }}$ November planting while the lowest (16) from the 10 December planting. Planting on 10 November also gave the longest leaf $(51.5 \mathrm{~cm})$, and 10 December planting gave the shortest one $(36.3 \mathrm{~cm})$. Seeding on the 20 and 30 of November produced second and third-ranked values of these parameters. It was observed that, from the 10 November planting, every ten days delay reduced the tuber yield by 30,43 , and $55 \%$, respectively, and all other plant characters significantly. 


\section{Effect of Genotypes}

Different genotypes exerted a significant effect on tuber yield $\left(t \mathrm{ha}^{-1}\right)$ and other plant characters except for the tuber girth (Figure 2). The highest tuber yield $\left(89.7 \mathrm{t} \mathrm{ha}^{-1}\right)$ was obtained from the genotype EB-0809, followed by Shubhra, Cauvery, EB0616, while EB-0626 gave the lowest beet yield $\left(58.91 \mathrm{t} \mathrm{ha}^{-1}\right)$. The highest number of plants $\mathrm{m}^{-2}(98)$ and the heaviest plant $\left(134.2 \mathrm{t} \mathrm{ha}^{-1}\right)$ was recorded from the genotype EB-0809. The lowest plant population and the thinnest plant was obtained from EB-0626. In the case of tuber length and the number of green leaf plant ${ }^{-1}$, the highest value $26.3 \mathrm{~cm}$, and 31 , respectively obtained from EB-0809, followed by Shubhra, Cauvery, EB0616, and EB-0626. The longest leaf $(50.6 \mathrm{~cm})$ was obtained from the EB-0809, followed by Shubhra, EB-0616, Cauvery, and EB-0626.

\section{The Combined Effect of Planting Dates and Genotypes}

The interaction effect of planting dates and genotypes on tuber yield and different plant characters was statistically significant at 5\% levels. We recorded the highest number of plant densities (99), the most decadent fresh plant (222.0 $\mathrm{t} \mathrm{ha}^{-1}$ ), the highest number (44), and most elongate leaves
$(64.4 \mathrm{~cm})$ have recorded in EB-0809 under the 10 November planting date.

On the other hand, the longest $(28 \mathrm{~cm})$ and widest $(38 \mathrm{~cm})$ tuber and the highest tuber yield $\left(157 \mathrm{t} \mathrm{ha}^{-1}\right)$ were recorded from the genotype EB-0809 when sown on 10 November. The lowest tuber yield $\left(44 \mathrm{t} \mathrm{ha}^{-1}\right)$ was observed in EB-0626 with 10 December planting interaction (Figure 4). The genotype Shubhra, Cauvery, and EB-0616 ranked second, third, and fourth, respectively, when sown on 20 and $30^{\text {th }}$ November dates. The lowest number (14) of thinnest $\left(63.8 \mathrm{t} \mathrm{ha}^{-1}\right)$ plant, the smallest $(15.9 \mathrm{~cm})$, and the most delicate $(22.5 \mathrm{~cm})$ tuber; moreover, the lowest number $(14)$ and shortest $(33.8 \mathrm{~cm})$ leaves was observed in EB-0626 when planted on 10 December date.

\section{DISCUSSION}

The above-stated results revealed that the tuber yield, including all other plant characters studied, gave the highest value on the 10 November planting of EB-0809. The values for all the parameters decreased gradually with planting after 10 November sown other genotypes. Variation of tuber yield might be due to the variation in the number of plant density $\mathrm{m}^{-2}$ and green leaves plant $^{-1}$ related to the leaf area index (LAI) associated with the

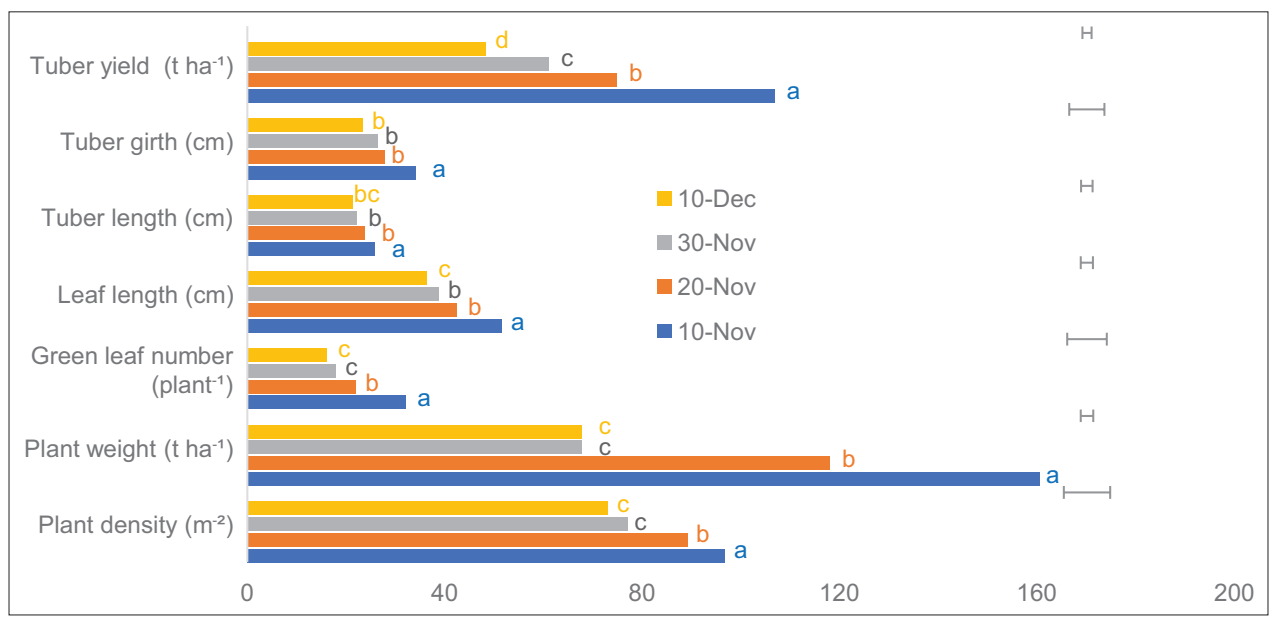

Figure 1: Effect of planting dates on the yield attributes and tuber yield of tropical sugar beet

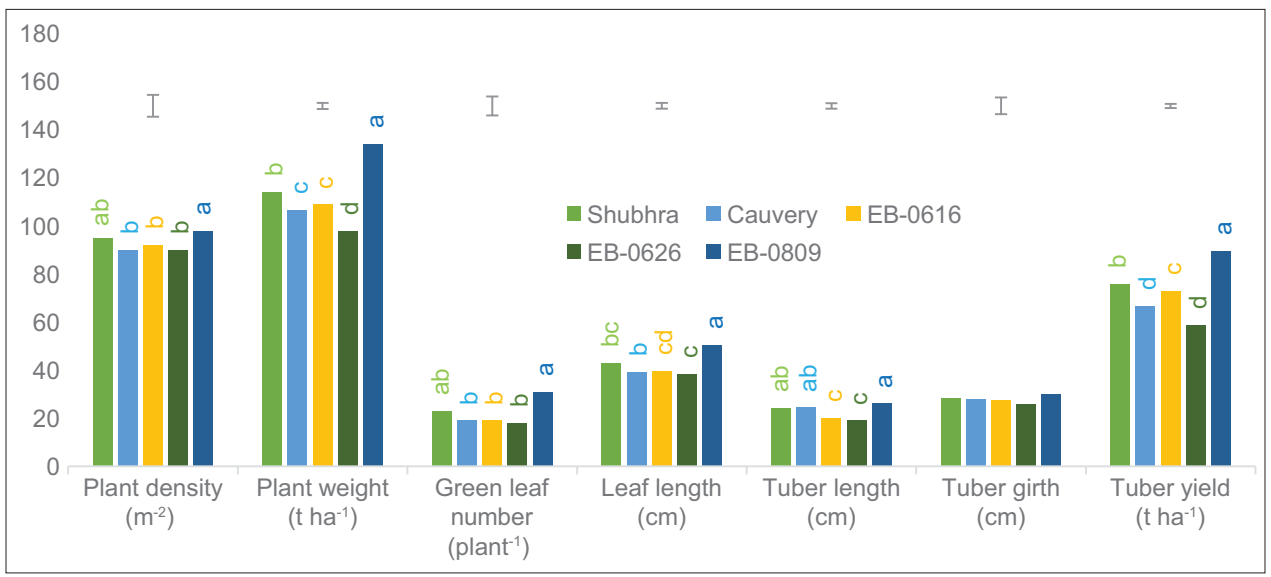

Figure 2: Effect of genotypes on the yield attributes and tuber yield of tropical sugar beet 


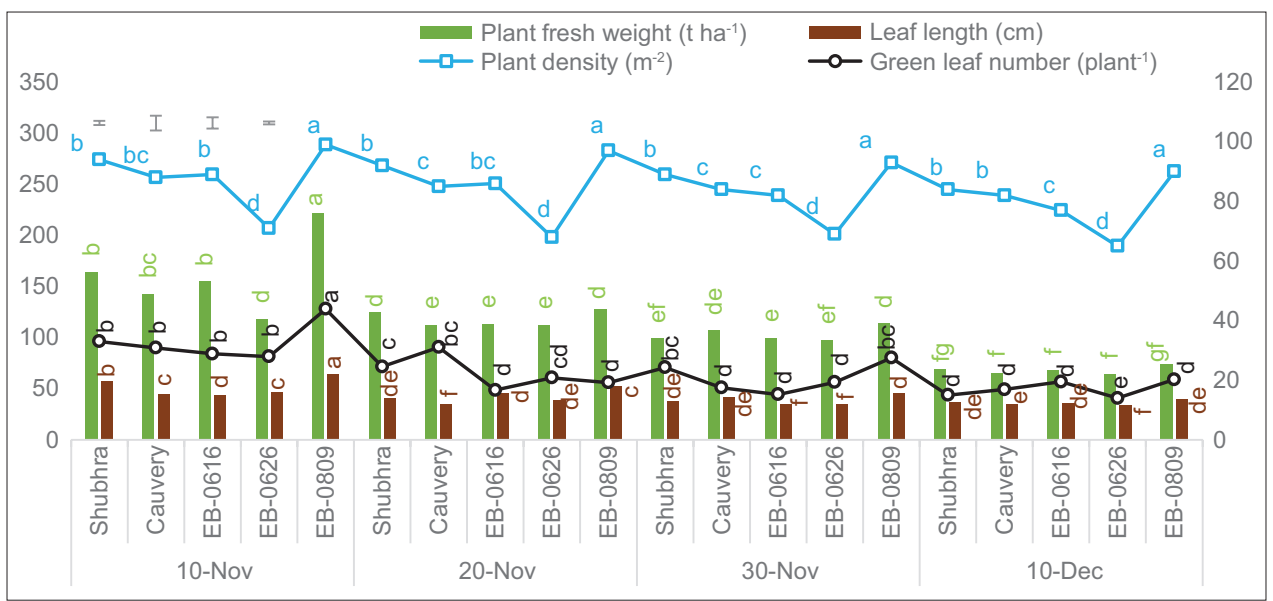

Figure 3: The combined effect of planting dates and genotypes on the plant parameters of sugar beet

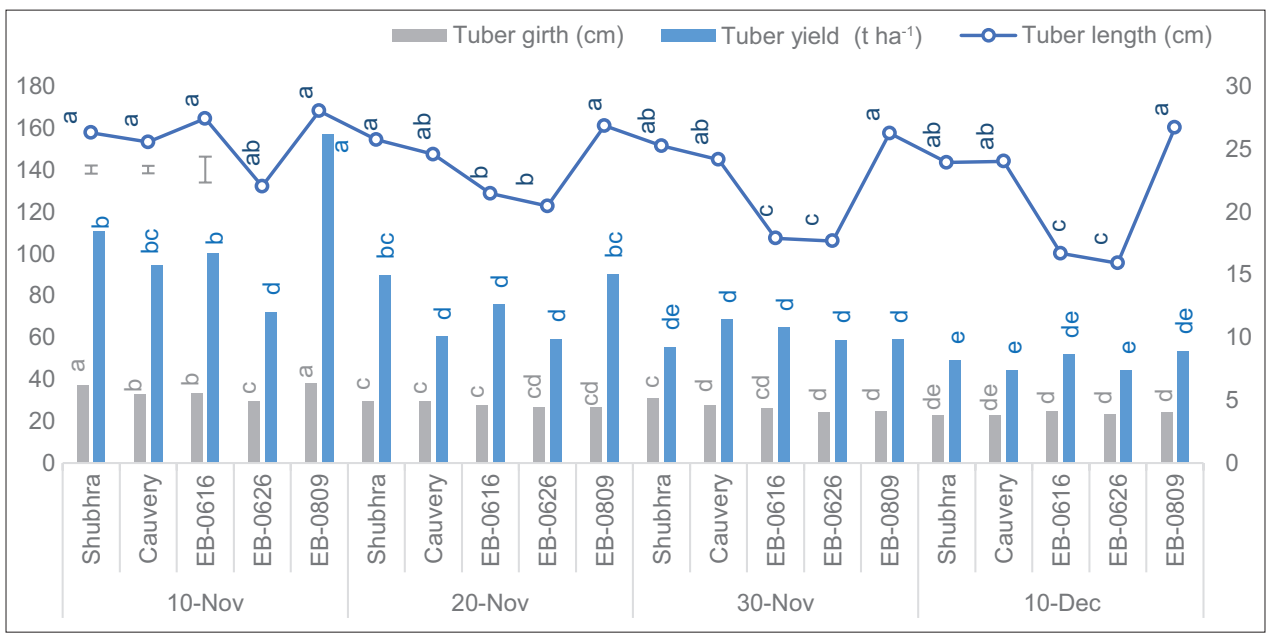

Figure 4: Combined effect of planting dates and genotypes on the tuber length, girth and yield of sugar beet

deviation of temperature ranges from the optimum required to obtain the highest values on the 10 November planting date. Planting on the 10 November might influence the better plant establishment than the later ones. Better plant establishment obtained from 10 November might be due to providing a better opportunity for increased LAI and, consequently, solar radiation interception and photosynthesis. Early crop establishment might offer a better chance to exploit the right weather conditions that lead to higher tuber yield during 10 November planting than on other dates. (Ramazan, 2002) concluded that early planting of sugar beet has the best germination and high root and sugar yields than the late planting affected due to low temperature. A delay in planting results in tuber weight and yield loss (Al-Jbawi et al., 2015). Leilah et al. (2005) concluded that planting sugar beet on 1 October produced the highest values of length, diameter, and fresh weight of roots, purity percentage, root, top, and sugar yields ha-1. Petkeviciene (2009) indicated that early planting reduced the plant density by $3.3 \%$ compared with the average $(99,900$ plants ha-1). He added a one-week delay in planting reduced tuber yield by $4.7 \mathrm{t} \mathrm{ha}^{-1}$ and white sugar $0.9 \mathrm{t} \mathrm{ha}^{-1}$ and increased alpha-amino nitrogen in roots by $2.58 \mathrm{mg} 100 \mathrm{~g}^{-1}$. Simultaneously, Nikpanah et al. (2015) showed early planting increased nitrogen level, maximum LAI, and dry matter accumulation. The reduction in the number of leaves plant ${ }^{-1}$ and LAI at the latter part of the growth that occurred from the late planting might be due to the death of older leaves, which could not be entirely replaced by that of the newly formed leaves. Variation of prevailing temperatures during later sown plant's root formation stages than early sown plants might affect the translocation of photosynthates to the tuber and cause high respiration loss, consequently reducing the tuber yield in this present study.

Furthermore, the effect of genotypes on the tuber yield and other plant parameters in our study revealed that among the five genotypes used, EB-0809 yielded the highest values for tuber yield, including all the plant characters, especially the number of leaves plant ${ }^{-1}$. The variation of genetic make-up leads to varying the yield potentials among the genotypes. Sanghera et al. (2017) and Curcic et al. (2018) found that the sugar beet production and quality depend on a thriving selection of promising genotypes and right growing conditions. Different genotypes possess the other potentiality of tuber yield that mostly influenced by the yield contributing characters like the plant density $\mathrm{m}^{-2}$ and leaves plant ${ }^{-1}$ (Kumar et al., 2019; Nofal et al., 2016) and importantly to fight against diseases and insects 
incidence, especially the sclerotium root rot disease and hairy caterpillar insect (Islam et al., 2013). Hence, it was evident from the present study that the highest tuber yield had produced by the genotype EB-0809 planted on 10 November might be due to better exploitation of environmental factors that facilitates the higher production and translocation of photosynthates from the source (leaves) to sink (tubers).

\section{CONCLUSIONS}

The present study revealed that both the planting date and genotype significantly affected the tuber yield and plant characters of tropical sugar beet. The results indicated that all the genotypes produced the higher tuber yield on 10 November planting than the planting on other study dates. The tuber yield decreased gradually with planting after 10 November. Overall, the genotype EB-0809 yielded the highest beet $\left(89.7 \mathrm{t} \mathrm{ha}^{-1}\right)$ among five genotypes. Finally, it might be concluded that the highest yield in tropical sugar beet could be obtained if genotype EB-0809 is sown on 10 November under the Agroecological condition of the Old Brahmaputra Floodplain of Bangladesh.

\section{ACKNOWLEDGMENT}

The authors would like to extend their heartfelt gratitude to the Committee for Advanced Studies and Research (CASR) of Bangladesh Agricultural University for funding this study.

\section{REFERENCES}

Al-Jbawi, E., Sabsabi, W., Gharibo, G., \& Omar, A. (2015). Effect of sowing date and plant density on bolting of four sugar beet (Beta vulgaris L.) varieties. International Journal of Environment, 4(2), 256-270.

Curcic, Z., Ciric, M., Nagl, N., \& Taski-Ajdukovic, K. (2018). Effect of sugar beet genotype, planting and harvesting dates and their interaction on sugar yield. Frontiers in Plant Science, 9, 1041. https://doi. org/10.3389/fpls.2018.01041

El-Hag, M., Ahmed, A., \& Ragga, P. (2015). Evaluation of sowing date and harvesting ages of some sugar beet (Beta vulgaris L.) cultivars under Guneid condition (Sudan). International Journal of Agriculture: Research and Review, 3(9), 421-424.

Gobarah, M., Hussein, M. M., Tawfik, M. M., Aahmed, A. G., \&
Mohamed, M. F. (2019). Effect of different sowing dates on quantity and quality of some promising sugar beet (Beta vulgaris L.) varieties under north delta condition. Egyptian Journal of Agronomy, 41(3), 343-354. https://doi.org/10.21608/agro.2019.20126.1197

Hossain, M., Qazi, A., \& Karim, A. (2015). Effect of sowing dates on growth and yield of tropical sugar beet. International Journal of Agronomy and Agricultural Research, 7(1), 53-60.

Islam, M., Ahmad, S., Uddin, M., \& Sattar, M. (2013). Evaluation of tropical sugarbeet genotypes under Bangladesh condition. Bangladesh Journal of Agricultural Research, 37(4), 721-728. https://doi. org/10.3329/bjar.v37i4.14396

Khan, I. K., Iqbal, M., \& Hashim, M. M. (2020). Impact of sowing dates on the yield and quality of sugar beet (Beta vulgaris L.) cv. CaliforniaKWS. Proceedings of Pakistan Academy of Sciences: B. Life and Environmental Sciences, 57(1), 51-60.

Kumar, D., Lamani, A., \& Halikatti, S. (2019). Performance of sugar beet (Beta vulgaris L.) to different dates of sowing under temperature regime. International Journal of Plant and Soil Science, 27(1), 1-12.

Leilah, A., Badawi, M., Said, E., Ghonema, M., \& Abdou, M. (2005). Effect of planting dates, plant population and ntrogen fertilization on sugar beet productivity under the newly reclaimed sandy soils in Egypt. Science Journal of King Faisal University, 6(1), 95-110.

Nikpanah, H., Seifzadeh, S., Hemayati, S., Shiranirad, A., \& Taleghani, D. (2015). Effects of management of agronomical factors on sugar beet steckling production and growth. International Journal of Bioinformatics Research and Applications, 7(2), 959-964.

Nofal, O., EIEila, H., \& El-Sayed, S. (2016). Relationships between soil characters and nutrients uptake of three sugar beet varieties grown in newly reclaimed soi. International Journal of ChemTech Research, 9(3), 60-65.

Paul, S. K., Paul, U., Sarkar, M. A. R., \& Hossain, M. S. (2018). Yield and quality of tropical sugarbeet as influenced by variety, spacing and fertilizer application. Sugar Tech, 20(2), 175-181. https://doi. org/10.1007/s12355-017-0545-3

Petkeviciene, B. (2009). The effect of climate factors on sugar beet early sowing timing. Agron Research, 7(1), 436-443.

Ramazan, C. (2002). Root yield and quality of sugar beet in relation to sowing date, plant population and harvesting date interactions. Turk Journal of Agriculture and Forestry, 26, 133-139.

Refay, Y. (2010). Root yield \& quality traits of three sugar beet (beta vulgaris I.) varieties in relation to sowing date and stand densities. World Journal of Agricultural Sciences, 6(5), 386-414.

Sanghera, G., Thind, K., Singh, N., Singh, R., \& Tyagi, V. (2017). Genotype $\times$ environment interactions and stability analysis for root yield and quality traits in sugarbeet (Beta vulgaris L.). Annals of Agricultural Research, 38(2), 235-241.

Singh, N., S Thind, K., \& Singh Sanghera, G. (2019). Interactive outcome of dates of sowing and genotypes over environments on root yield and quality attributes in sugarbeet (Beta vulgaris L.). Acta Scientific Agriculture, 3(10), 164-172. https://doi.org/10.31080/ asag.2019.03.0663 